\title{
Teacher motivation: A study of work motivation of the primary stage teachers in Jordan
}

\author{
Emad Mhammad Jamil Al-Salameh
}

Al- Balqa' Applied University- Princess Rhama University College-Special Education Department, Al-Salt 19117- Jordan

\section{Email address:}

imad_alsalameh@yahoo.com

\section{To cite this article:}

Emad Mhammad Jamil Al-Salameh. Teacher Motivation: A Study of Work Motivation of the Primary Stage Teachers in Jordan. American Journal of Applied Psychology. Vol. 3, No. 3, 2014, pp. 57-61. doi: 10.11648/j.ajap.20140303.12

\begin{abstract}
This study aims to investigate the work motivation of the primary stage teachers in relation to age, type of school, educational qualifications, and gender. To fulfill this, three hundred and twelve participants were selected randomly by stratified method from government and private schools in Balqa governorate. The finding of the study revealed: i) The primary stage teachers in Jordan have relatively good level of work motivation ii) No significant difference was found in the work motivation among teachers working in government and private schools iii) No significant difference was found in the work motivation of teachers due to the age iv) There were significant differences in the work motivation of male and female teachers, specifically, our results suggest that female teachers were found to be more motivated to their work than male teachers v) Significant difference was reported in the work motivation of teachers having bachelor and high diploma qualification, the analyses revealed that the teachers having bachelor were found to be more motivated to their work than the teachers having high diploma.
\end{abstract}

Keywords: Work Motivation, Teacher Motivation, Type of School, Educational Qualifications

\section{Introduction}

Teachers are arguably the most important group of professionals for any nation's future. Therefore, it is disturbing to find that many of today's teachers are unenthusiastic with their jobs. It is well known that many teachers lose or fail to develop self-efficacy within educational settings (Dweck, 1999). In addition, needs satisfaction and motivation to work are very essential in the lives of teachers because they form the fundamental reason for working in life. While almost every teacher works in order to satisfy his or her needs in life, he or she constantly agitates for need satisfaction. Job satisfaction in this context is the ability of the teaching job to meet teachers' needs and improve their job/teaching performance. It is crucial that we determine what increases teacher motivation. Many factors have been examined in attempt to find which ones promote teacher motivation. Pay incentives alone have been found to be unsuccessful in increasing motivation, schemes such as merit pay were predicted to be counterproductive; true job satisfaction is derived from the gratification of higher-order needs, "social relations, esteem, and actualization" rather than lower-order needs. Sylvia and Hutchinson (1985) confirmed that teacher motivation is based in the freedom to try new ideas, achievement of appropriate responsibility levels, and intrinsic work elements. The relevance of job satisfaction and motivation are very crucial to the long-term growth of any educational system around the world. They probably rank alongside professional knowledge and skills, center competencies, educational resources and strategies as the veritable determinants of educational success and performance. Professional knowledge, skills and center competencies occur when one feels effective in one's behavior (Filak \& Sheldon, 2003).

The term employee motivation is a complex and difficult term to define; therefore a precise definition of this concept is elusive as the notion comprises the characteristics of individual and situation as well as the perception of that situation by the individual (Ifinedo, 2003; Rosenfeld \& Wilson, 1999). Motivation has been defined in several ways. It can be described as the need or drive that incites a person to some action or behavior, the verb "motivate" means to provide reasons for action. Motivation is crucial and important in everything we do, especially at the work place. If we do not feel driven to do our job then the work will not be successfully accomplished. Hoy and Miskel (1987) demonstrated that employee motivation is the complex forces, drives, needs, tension states, or other mechanisms that 
start and maintain voluntary activity directed towards the achievement of personal goals. Dessler (2001) defined motivation as the intensity of a person's desire to engage in some activity. A great number of theories, models and concepts tackle the issue and it has been discussed in various articles and books. Motivation is a frequently disputed topic and viewed as a critical subject within the field of organizational behavior. Having employees that are motivated when performing their work is a prime objective for managers (Alvesson, 2004). Humans are motivated to work by different things; it can be everything from money to a flexible schedule; our life situation and external circumstances are the main decisive factors. This indicates that motivation is extremely personal; even if two individuals are exposed to the same situation they would still react in various ways and be motivated by totally different factors.

The studies today famous on identifying the importance of social needs in the workplace, and the whole question of work motivation became a burning issue. The relation between individuals and groups also woke attention, and new theories of organizational life began to emerge. With this, it became clear that employees being committed and motivated in their work resulted in higher production levels and hence reduced costs (Steers \& Porter,2003). However, no consensus exists on the extent to which financial inducements are the really critical motivators. Research has shown that monetary reward in itself has not improved teachers' low esteem and their productivity.

Saeed and Muneer (2012) indicated that female teachers were found to be more motivated to their work than male teachers. Gupta and Gehlawat (2013) reported that no significant difference in the work motivation of male and female teachers, teachers working in private schools possessed significantly higher work motivation than those working in government schools, less experienced teachers possessed significantly higher work motivation than the more experienced teachers. teachers graduate qualifications possessed significantly higher work motivation than the post-graduate qualifications. Gupta, Pasrija and Bansal (2012) reported that female teachers were more motivated in their jobs than male teachers. Kaur and Sidana (2011) found that level of work motivation of male teachers was greater than their female counterparts. Srivastava and Krishna (1994) indicated that the 'need for achievement' and 'self-control' were the most dominant motivating forces for male as well as female teachers whereas the 'monetary gain' was the least effective motivator for them. Christian and Torsten (2012) findings showed that age was positively associated with motivation for generativelyrelated, but not growth-related tasks. Personal and job resources were positively. Kumar, Udayasuriyan and Vimala (2008) reported significant differences in work motivation based on the demographic variables such as age, gender, teaching experience in the present organization, marital status and monthly income. Laura et al, (2012) examined the effects of two types of motivation, driven to work and enjoyment of work. The authors also tested the effects of self-esteem on the two motives. They found that the enjoyment motive was positively related to career satisfaction and performance and negatively related to strain. Driven to work had no main effects but appeared to interact with enjoyment of work to influence performance and strain. When enjoyment of work was high, driven to work was unrelated to performance or strain. When enjoyment of work was low, increases in driven to work were associated with increases in both performance and strain. Self-esteem was positively related to enjoyment of work and negatively related to driven to work. Overall, the authors' findings suggest that being motivated by enjoyment of work facilitates both effectiveness and wellbeing. Rachita and Piyali (2012) indicated that public employees are motivated by achievement and self-control, whereas in the private sector, employees value job involvement, pride in work, upward striving, and activity preference. Samina et al, (2011) suggested that the same type of the factors of extrinsic and intrinsic rewards are not equally applicable in both the public and private sector organizations to increase the work motivation. Shiraz et al, (2011) pointed that variables such as work content, working conditions and career growth were found as key predictors to employee motivation. Comparatively career growth was found as the most parsimonious variable in explaining employees' work motivation. Implications of the study are also presented.

Studies show that improvement in teacher motivation has benefits for students as well as teachers; however it is likely that high levels of teacher social interaction on the job are linked to high motivation levels; thus, the possibility that enhanced levels of teacher motivation will lead to superior student achievement cannot be dismissed. Rothman (1981) suggests that this association exists because teachers serve as more than just educators; they are role models. Similarly, the roles and contexts of educations' motivational methods and tools cannot be under emphasized because high motivation enhances productivity which is naturally in the interests of all educational systems (Ololube,2005).Thus, it is assumed that the current study will provide a new information and perspective describing work motivation of the primary stage teachers in Jordan.

\section{Study Questions}

i. What is the level of work motivation among the primary stage teachers in Jordan?

ii. Are there statistically significant differences in work motivation of the primary stage teachers in Jordan due to the type of school?

iii. Are there statistically significant differences in work motivation of the primary stage teachers in Jordan due to gender?

iv. Are there statistically significant differences in work motivation of the primary stage teachers in Jordan due to age?

v. Are there statistically significant differences in work 
motivation of the primary stage teachers in Jordan due to educational qualifications?

\section{Methods}

\subsection{Participants}

Three hundred and twelve participants completed all conditions of this study. Among participants, 156 were male and 156 were female.

\subsection{Instrument}

Considered work motivation scale prepared by the researcher after reference to the literature about work motivation, specially Hawthorne Studies and Abraham Maslow theory. The scale was used to measure each participant's work motivation. This scale is a 45 -item selfreport questionnaire containing a 4-point Likert response scale, ranging from 1 (never) to 4 (always). This scale has high internal consistency, $\alpha=0.83$.

\section{Results and Discussion}

Results indicated that the primary stage teachers in Jordan as a whole have relatively good level of work motivation $(\mathrm{M}=3.13, \mathrm{SD}=0.211)$. ( see table 1$)$.

Table 1. Descriptive analysis results

\begin{tabular}{llccc}
\hline $\begin{array}{l}\text { Dependent } \\
\text { Variables }\end{array}$ & Items & M & SD & N \\
\hline \multirow{2}{*}{ Type of School } & Govt & 3.12 & 0.210 & 156 \\
& private & 3.13 & 0.212 & 156 \\
Gender & Male & 3.11 & 0.219 & 156 \\
& Female & 3.15 & 0.200 & 156 \\
& $<30$ years & 3.13 & 0.193 & 90 \\
Age & 31 to 40 years & 3.12 & 0.198 & 140 \\
& 41 years or above & 3.15 & 0.249 & 82 \\
& Diploma & 3.19 & 0.214 & 93 \\
Educational & Bachelor & 3.20 & 0.336 & 203 \\
Qualification & High Diploma & 2.96 & 0.267 & 13 \\
& Master & 3.20 & 0.231 & 3 \\
Total & & 3.13 & 0.211 & 312 \\
\hline
\end{tabular}

The finding of the study revealed that there was no significant difference in work motivation among teachers working in government $(\mathrm{M}=3.12, \mathrm{SD}=0.210)$ and private $(\mathrm{M}=3.13, \mathrm{SD}=0.212)$ schools; $\mathrm{t}(310)=0.459, \mathrm{p}=0.646$. These results suggest that the type of school doesn't have an effect in work motivation of the primary stage teachers. (see table 2). This finding is contrast with the finding of Gupta and Gehlawat (2013) who revealed that the teachers working in private schools were more motivated to work than those working in the government schools.

Table 2. T- test table (School type as DV)

\begin{tabular}{cccccccc}
\hline $\begin{array}{c}\text { Dependent } \\
\text { Variable }\end{array}$ & Items & $\mathbf{M}$ & SD & $\mathbf{N}$ & $\mathbf{t}$ & df & Sig \\
\hline & Govt & 3.12 & 0.210 & 156 & & & \\
Type of School & & & & & 0.459 & 310 & 0.646 \\
& private & 3.13 & 0.212 & 156 & & & \\
\hline
\end{tabular}

Note. $\mathrm{p}<.05$

Results indicated a significant difference in the work motivation of male $(\mathrm{M}=3.11, \mathrm{SD}=0.219)$ and female $(\mathrm{M}=3.15, \mathrm{SD}=0.200)$ teachers; $\mathrm{t}(310)=2.010, \mathrm{p}=0.045$. These results suggest that there was a significant effect for gender on work motivation of the primary stage teachers. Specifically, our results suggest that female teachers were found to be more motivated to their work than male teachers. (see table 3).Suggesting that female teachers found that teaching saturates their psychological needs and accommodates their role better than other jobs. The present finding is in agreement with the finding of Saeed and Muneer (2012)., Gupta, Pasrija and Bansal (2012) who indicated that female teachers were found to be more motivated to their work than male teachers. But it is disagreement with the finding of Gupta and Gehlawat (2013) who reported that no significant difference in the work motivation of male and female teachers, and with the finding of Srivastava and Krishna (1994)., Kaur and Sidana (2011) who indicated that the male teachers were found to be more motivated to their work as compared to the female teachers.

Table 3. T- test table (Gender as DV)

\begin{tabular}{cccccccc}
\hline Dependent Variable & Items & M & SD & N & df & & \\
\hline \multirow{2}{*}{ Gender } & Male & 3.11 & 0.219 & 156 & 2.010 \\
& Female & 3.15 & 0.200 & 156 & & \\
\hline
\end{tabular}

Note. $p<.05$

Preferences for age did not differ significantly across the three levels, $\mathrm{F}(.018)=.414, \mathrm{p}=.662$.(see table 4 ). This finding is contrast with the finding of Gupta and Gehlawat
(2013) who revealed that less experienced teachers possessed significantly higher work motivation than the more experienced teachers. 
Table 4. One-Way ANOVA table (Age as DV)

\begin{tabular}{clccclccccc}
\hline $\begin{array}{c}\text { Dependent } \\
\text { Variable }\end{array}$ & Items & M & SD & N & Sources & $\begin{array}{c}\text { Sum of } \\
\text { squares }\end{array}$ & df & $\begin{array}{c}\text { Mean } \\
\text { square }\end{array}$ & F & Sig \\
\hline \multirow{2}{*}{ Age } & $<30$ years & 3.13 & 0.193 & 90 & Between Groups & 0.037 & 2 & 0.018 & \\
& 31 to 40 years & 3.12 & 0.198 & 140 & Within Groups & 13.774 & 309 & & 0.414 & 0.662 \\
& 41 years or above & 3.15 & 0.249 & 82 & Total & 13.811 & 311 & 0.045 & & \\
\hline
\end{tabular}

Note. $\mathrm{p}<.05$

Preferences for educational qualifications differed significantly across the three levels, $F(.241)=2.655, \mathrm{p}$ $=.049$. Post Hoc analyses were performed using the Scheffe' tests to identify exactly where significant differences exist. The analyses revealed that high diploma differed significantly from the bachelor $(\mathrm{ps}<.05)$. No other differences were found.(see table 5\&6). Results suggest that teachers having bachelor were found to be more motivated to their work than the teachers having high diploma, suggesting that getting a high diploma degree mostly a shift from teaching to administrative work, so staying in the teaching profession after receiving a high diploma degree may causes frustration and reduces their work motivation. The present finding is in agreement with the finding of Gupta and Gehlawat (2013) who indicated that teachers graduate qualifications possessed significantly higher work motivation than the post-graduate qualifications.

Table 5. One-Way ANOVA table (Academic Degree as DV)

\begin{tabular}{|c|c|c|c|c|c|c|c|c|c|c|}
\hline $\begin{array}{l}\text { Dependent } \\
\text { Variable }\end{array}$ & Items & M & SD & $\mathbf{N}$ & Sources & $\begin{array}{c}\text { Sum of } \\
\text { squares }\end{array}$ & df & $\begin{array}{c}\text { Mean } \\
\text { square }\end{array}$ & $\mathbf{F}$ & Sig \\
\hline \multirow{4}{*}{$\begin{array}{l}\text { Educational } \\
\text { Qualifications }\end{array}$} & Diploma & 3.19 & 0.214 & 93 & \multirow{4}{*}{$\begin{array}{l}\text { Between Groups } \\
\text { Within Groups } \\
\text { Total }\end{array}$} & \multirow{4}{*}{$\begin{array}{c}0.723 \\
27.967 \\
28.690\end{array}$} & \multirow{3}{*}{$\begin{array}{c}3 \\
308\end{array}$} & \multirow{3}{*}{0.241} & \multirow{4}{*}{2.655} & \multirow{4}{*}{0.049} \\
\hline & Bachelor & 3.20 & 0.336 & 203 & & & & & & \\
\hline & High Diploma & 2.96 & 0.267 & 13 & & & & & & \\
\hline & Master & 3.20 & 0.231 & 3 & & & 311 & 1 & & \\
\hline
\end{tabular}

Note. $\mathrm{p}<.05$

Table 6. Post Hoc Tests table

\begin{tabular}{llcc}
\hline Educational Qualification & Items & Mean Difference & Sig \\
\hline \multirow{3}{*}{ Diploma } & Bachelor & -0.009 & 0.996 \\
& High Diploma & 0.234 & 0.078 \\
& Master & -0.005 & 1.000 \\
Bachelor & Diploma & 0.009 & 0.996 \\
& High Diploma & $0.243 *$ & 0.049 \\
& Master & 0.004 & 1.000 \\
High Diploma & Diploma & -0.234 & 0.078 \\
& Bachelor & $-0.243 *$ & 0.049 \\
Master & Master & -0.239 & 0.674 \\
& Diploma & 0.005 & 1.000 \\
& Bachelor & -0.004 & 0.000 \\
\hline
\end{tabular}

\section{Conclusion and Applications}

The study of work motivation is of much value to administrators and policy makers. Therefore, this study seeks to draw the attention of administrators in particular to the fact that their practices and behaviors must work to motivate teachers. Administrators must become more sensitive and become more aware of their teachers' needs, for it is incumbent that they motivate teachers and to keep their enthusiasm and interest in work high. Administrators can organize special welfare programs for teachers' wellbeing and positive changes in their level of work motivation. As far as improving the factors related to the job. Providing a good working environment and giving teachers more resources are not quite enough, for when the higher order needs such as esteem and self-actualization needs are met, the greater would be teachers' movement towards a higher stage of development. Also, the administrators should provide the opportunity for suitable working space, facilities to achieve one's status and prestige in job etc. The teachers having different levels of work motivation; teachers high in extrinsic work motivation may prefer bonuses other types of reward. Therefore, it is very necessary to identify teachers' drives and needs and to channelize their behavior to motivate them towards task performance. The administrators need to rethink their motivational practices, though monetary benefits play a crucial role in motivating the teachers but it has also been discovered that one of the best ways to motivate the teachers is praise and recognition, because everybody needs encouragement and everybody needs their work to be recognized. 


\section{Limitations}

Current study had several limitations. This study was primarily limited by validity and reliability coefficients for the scale which is used. Also, the study was limited to the primary stage teachers in Balqa governorate schools during the academic year 2013/2014.

\section{Acknowledgements}

My thanks are also expressed to Al- Balqa' Applied University (BAU). "This work has been carried out during sabbatical leave granted to the author from Al- Balqa' Applied University (BAU) during academic year 2013/2014".

\section{References}

[1] Alvesson, M. (2004). Knowledge Work and Knowledge Intensive Firms. Oxford Press, New York.

[2] Christianm, S., Torsten, B. (2012). Ageing and work motivation: a task-level perspective. Journal of Managerial Psychology, $27 \quad$ (5), pp. 459-478, doi: $10.1108 / 02683941211235382$.

[3] Dessler, G. (2001). Management: Leading People and Organization in the 21 st Century. Harlow :Prentice Hall.

[4] Dweck, C. (1999). Self-theories: Their Role in Motivation, Personality, and Development. Philadelphia, PA: Psychology Press.

[5] Filak, V., Sheldon, K. (2003). Student Psychological Need Satisfaction and College Teacher-Course Evaluations. Educational Psychology, 23 (3), pp. 235-247.

[6] Freyedon, A., Porter, A. (2012). Survey the Main Factor Impact on Work Motivation. International Journal of Learning \& Development, 2 (1), pp. 85-94, doi:10.5296/ijld.v2i1.1254.

[7] Gupta, M., Pasrija, P., Bansal, K. K. (2012). Job Satisfaction of Secondary School Teachers in Relation to some Demographic Variables: A Comparative Study, Journal of Education and Research for Sustainable Development,1(1), pp. 8-17.

[8] Gupta, M., Gehlawat, M. (2013). Job Satisfaction and Work Motivation of Secondary School Teachers in Relation to Some Demographic Variables: A Comparative Study, Educational Confab, 2 (1), pp. 10-19.

[9] Hoy, W., Miskel, C. (1987). Educational Administration: Theory, Research and Practice. New York: Random House.

[10] Ifinedo, P. (2003). Employee Motivation and Job Satisfaction in Finnish Organizations: A Study of Employees in the Oulu Region, Finland. Master of Business Administration Thesis, University of London.
[11] Ilke, I., Jesse, S., \&Dave, B. (2012). Age-related differences in work motivation. Journal of Occupational \& Organizational Psychology, 85 (2), pp. 300-329, doi:10.1111/j.2044-8325.2011. 02035.x.

[12] Kaur, G., \& Sidana, J. J. (2011). Job satisfaction of college teachers of Punjab with respect to area, gender and type of institution, Edutracks, 10 (11), pp. 27-35.

[13] Kumar, M. S., Udayasuriyan, G., \& Vimala, B. (2008). Motivation among the employees of a public sector concern, Journal of Community Guidance and Research, 25 (3), pp. 340-351.

[14] Laura, M., Marian, N., patrian., J., \& Todd, W. (2012). Driven to work and enjoyment of work: effects on managers outcomes. Journal of Management, 38 (5), pp. 1655-1680, dio: $10.1177 / 0149206310363612$.

[15] Maslow, A. (1987). Motivation and Personality, third edition, Harper Collins Publishers: New York.

[16] Ololube, N. P. (2005). Benchmarking the Motivational Competencies of Academically Qualified Teachers and Professionally Qualified Teachers in Nigerian Secondary Schools. The African Symposium,5(3). pp. 17-37.

[17] Rachita, S., Piyali, G. (2012). Work values and employee motivation in the private and public business enterprises in India. International Journal of Human Resources Development \& Management, 12 (3), pp. 237-253.

[18] Rosenfeld, R., Wilson, D. (1999). Managing Organizations: Text, Readings and Cases, London: McGraw-Hill.

[19] Rothman, E. (1981). Troubled Teachers. D. McKay: New York.

[20] Saeed, A., Muneer, R.( 2012). Work motivation of male and female secondary school teachers in Karachi. Interdisciplinary Journal of Contemporary Research in Business, 4(6), pp. 462-467.

[21] Samina, N., Jawwad, A., \& Shafi, K. (2011). An analysis of differences in work motivation between public and private sector organizations. Interdisciplinary Journal of Contemporary Research in Business, 2 (11), pp. 110-127.

[22] Shiraz, K., Adnan, R., \& Majed, R. (2011). The impact of work content, working conditions, career growth on employee motivation. Interdisciplinary Journal of Contemporary Research in Business, 3 (3), pp. 1428-1434.

[23] Srivastava, A. K., \& Krishna, A. (1994). Work motivation and job involvement of male and female teachers: A comparative study, Journal of Psychological Researches, 38(1\&2), pp. 52-59.

[24] Steers, R. (2003). Motivation and Work Behavior, Seventh Edition, McGraw-Hill: New York.

[25] Sylvia, R., Hutchinson, T. (1985). A Study of teacher motivation. Human Relations, 38, pp. 841-56. 